\title{
THE DEAR DIANE LETTERS AND THE BINTEL BRIEF: THE EXPERIENCES OF CHINESE AND JEWISH IMMIGRANT WOMEN IN ENCOUNTERING AMERICA
}

\author{
Hong Cai \\ University of Kansas
}

Especially influenced by feminism, post-structuralism, and post-ethnic theories and methodologies, women's/gender studies has developed a multifaceted and ever-changing discursivity in recent decades. Research on race, gender and ethnicity provides scholars with a rich site on which to discuss the meaning of such important concepts as "race," "subjectivity," "sexuality," "body," "class," and "religion." Since the passage of new immigration laws in the 1960s, this has been especially pronounced by an influx of a large number of immigrants into the United States. Studies of immigrant women involve a broader context of relevant research. As scholar Donna Gabaccia argues, studies of immigrants, ethnics, and women share "common roots in some ways" and there has been a flowering research on immigrant women since the 1970s. ${ }^{1}$ This "intersectional" study of immigrants is also echoed in scholar Justin Allen Burg's recent research, in which he points out the importance of studying immigrants by combining race, class, gender, and social space together. ${ }^{2}$

The study of minority women is of ten related to the study of entire ethnic groups. In other words, the study of how immigrant women assimilate, adjust or even resist American society and culture is ingrained in the study of the immigrant minority group. The results of such studies often apply to the study of women/gender and, consequently, they benefit one by expanding one's vision and deepening one's understanding of the specific characteristics that different immigrant women groups possess.

Although one seldom lumps the study of Chinese and Jewish women together because of their different ethnic backgrounds and times of arrival in the United States, they share many common experiences. For example, both groups of women immigrants encountered difficulties dur-

1 Donna Gabaccia, "Immigrant Women: Nowhere At Home?," Journal of American Ethnic History, 10 (Summer 1991): 61-87.

2 Justin Allen Berg, "Race, Class, Gender, And Social Space: Using an Intersectional Approach to Study Immigration Attitudes," The Sociological Quarterly, 51(Spring 2010): 278302. 
ing the process of adapting to American society and culture. Although different in many other aspects, such as immigration history, language, culture, traditions, and customs, both Chinese and Jewish American women expressed similar frustrations, anxieties, and hopes while immigrating and adapting to American life. In this context, a comparative study of Chinese and Jewish women enables one not only to restore the ignored voice in history, but also, more important, helps one to map out the common territories of their immigrant lives.

It was a coincidence that while assimilating to American life, both Chinese and Jewish women immigrants received advice in a questionand-answer format. The advice column of the Jewish Daily ForwardBintel Brief-and the book for young urban Chinese women-Dear Diane: Questions and Answers For Asian American Women (1983)-offered guidance in adjusting to America. Although some of the writers of the Bintel Brief letters are new immigrants, more and more second- and third-generation writers contribute letters over time about their experiences growing up in the United States. Likewise, the writers of the letters in the Dear Diane book are mostly young urban second-generation Chinese American females. In both cases, the questions and answers, from different perspectives, provide scholars with an opportunity to study how race, gender, ethnicity, and culture play a role in their adaptation and assimilation to American life.

In the context of globalization, a consideration of transnationalism is helpful in analyzing the immigrant experiences of Chinese and Jewish American women. In her study of new immigrants, scholar Deborah Dash Moore finds that the resumption of immigration which brought a large number of immigrants mainly from Asia and South America to the United States has produced new models of migration theory, of which the most notable is the concept of transnationalism, "which in turn has raised anew questions about the children of immigrants, the second generation." 3 As a social movement, transnationalism grew out of the enhanced interconnectivity between people and the loosening boundaries between countries. The term transnationalism was coined by Randolph Bourne in his essay Trans-National America (1916) to describe a new way of thinking about relationships between cultures. According to Bourne, "America is coming to be, not a nationality but a trans-nationality, a weaving back and forth, with the other lands, of many threads of all sizes and colors." 4 To some extent, transnationalism has designated a

3 Deborah Dash Moore, "At Home in America?: Revisiting the Second Generation" in Immigration, Incorporation and Transnationalism, ed. Elliot Robert Barkan (New Brunswick: Transaction Publishers, 2007), 143-154.

4 Randolph S. Bourne, "Trans-National America" in World War Issues and Ideals: Readings in Contemporary History and Literature, eds. Morris Edmund Speare and Walter Blake Norris (Boston: Ginn and Company, 1918), 348. 
recent shift in migration patterns, where a point of departure and a point of arrival have turned into an ongoing movement between two or more social spaces. Indeed, facilitated by the advancement of technology and business on a global scale, immigrants have increasingly developed strong transnational ties to their home countries, thus bringing the social space and geographical space together.

In a historic context, however, assimilation theory is useful in viewing young urban Chinese and Jewish American women's experiences. One of its main points is that the distinctive culture of a minority will eventually erode and the minority's cultural values, social institutions, and ethnic identity will eventually give way to those of the dominant group. ${ }^{5}$ As early as 1926, one of the earliest assimilation theorists, Robert Ezra Park, advanced his theory of assimilation. He put forward the theory of a race relations cycle from "contacts," "competition," "accommodation," and eventually "assimilation."6 Later in 1961, in his article "Assimilation in America," Milton Gordon greatly enriched and redefined the theory of assimilation. He argues that previous theories of "Anglo-conformity," "melting pot," and "cultural pluralism" were concepts too idealized to be acceptable paradigms. Instead, Gordon argues that assimilation should be viewed more broadly and comprehensively. According to Gordon, assimilation is by no means a single phenomenon. Rather, it involves many different types. The three most important are: cultural assimilation, structural or social assimilation, and marital assimilation. ${ }^{7}$ Cultural assimilation refers to the minority group's acquisition of the cultural characteristics of the dominant group and structural assimilation looks at social interaction among individuals of different ethnic and racial backgrounds. In addition, marital assimilation involves intermarriage among different ethnic or racial groups. ${ }^{8}$ Gordon's theory was further developed by other scholars, such as Herbert Gans and Neil Sandberg, who predicted increasing assimilation in a sequence of generational steps. ${ }^{9}$

In his 1995 article "Revisiting Assimilation," Russell Kazal examines comprehensively the history and the enduring influence of assimilation theory. In doing so, he finds that after the collapse of the idea of an Anglo-Saxon "core" American society in the 1960s, to which everyone

5 Norman Yetman, "Patterns of Ethnic Integration in America," in Majority and Minority: The Dynamics of Race and Ethnicity in American Life, 6th Edition, ed. Norman Yetman (Boston: Allyn and Bacon, 1999), 229.

6 Ibid.

7 Ibid.

8 Ibid., 238-239.

9 Herbert Gans, introduction to Ethnic Identity and Assimilation: The Polish-American Community: Case Study of Metropolitan Los Angeles, by Neil Sandberg (New York: Praeger Publishers, 1974), vii-xiii. 
was presumed to assimilate, there was an urgent need for scholars to redefine assimilation. ${ }^{10}$ In 2003, Richard Alba and Victor Nee, for the first time, substantially analyzed the characteristics of current immigrant assimilation since Stanley Lieberson's 1980 A Piece of a Pie made a systematic comparative study of immigrant assimilation. In their book, Alba and Nee define assimilation as a form of ethnic change. In other words, they believe that assimilation is "the decline of an ethnic distinction and its corollary cultural and social differences." ${ }^{11}$ Accordingly, they suggest, the traditional European immigration pattern has given way to a new mass immigration pattern beginning in the late 1960s. In contrast to the old immigration pattern, "the new immigrants hail predominantly from the developing societies of Latin America, Asia, and the Caribbean Basin."12 By comparing the experiences of immigrants to the United States in the late nineteenth century (from Europe and East Asia) and twentieth century (from Latin America, Asia, and the Caribbean Basin), Alba and Nee find that assimilation is still a continuing pattern in shaping the immigrant experience. ${ }^{13}$

The book Dear Diane: Questions and Answers For Asian American Women was a response to the appearance of young Asian women immigrants in the 1960s and 1970s. It appeared in 1983 in three editions: English, English-Chinese, and English-Korean. In the Chinese and Korean language editions, the title reads Dear Diane: Letters From Our Daughters. ${ }^{14}$ The Dear Diane book was a collective enterprise. The publisher was Asian Women United (AWU) of California, an organization founded in 1976 by a group of Asian American women in the San Francisco Bay Area with a mission to "explore the many facets of Asian American women's experiences and varied cultural heritages through publications and video productions." 15 The Dear Diane project was also launched by AWU under the leadership of its director, Elaine Kim, the co-founder and former president at AWU. The writer, Diane Yen-Mei Wong, who was the former Chinatown Youth Director and Commissioner of the Office of Asian American Affairs in the State of Washing-

10 Russell Kazal, "Revisiting Assimilation: The Rise, Fall, and Reappraisal of a Concept in American Ethnic History," in Majority and Minority, ed. Norman Yetman, 303.

11 Richard Alba and Victor Nee, Remaking the American Mainstream: Assimilation and Contemporary Immigration (Massachusetts: Harvard University Press, 2003), 11.

12 Ibid., ix.

13 Ibid., $x$.

14 Diane Yen-Mei Wong, Dear Diane: Questions and Answers For Asian American Women (Oakland, California: Asian Women United of California, 1983) (English Edition); Diane Yen-Mei Wong, Dear Diane: Letters from Our Daughters (Oakland, California: Asian Women United of California, 1983) (Chinese Edition). They are abbreviated as the Dear Diane book or letters in this article unless specified otherwise.

15 Asian Women United (AWU), “Asian Women United of California," accessed March 31, 2011, http://www.asianwomenunited.org/. 
ton, wrote all the answers to the letters from Asian-American women, primarily young Chinese and Korean women.

Between 1980 and 1981, AWU surveyed over 600 immigrant and American-born Chinese and other Asian American female students in San Francisco Bay area high schools, colleges, and universities. In her book, Wong provides answers to the questions that these young urban female immigrants and students asked concerning their hopes, dreams, and the problems they faced in their daily life and work. One of the purposes of this project launched by AWU, according to Elaine Kim, was to help young Asian women to better adjust themselves and fit into an American way of life. As Kim states:

We are presenting these letters to you as an attempt to facilitate better and better communication and understanding between Asian parents and daughters, particularly in immigrant families, where anguish and confusion often results when cultures and customs collide. ${ }^{16}$

The Bintel Brief letters were originally printed by the newspaper The Jewish Daily Forward, which was founded in 1897 to serve Eastern European Jewish immigrants, and in the process, help them adjust to American society. As Issac Metzker argues, the Jewish Daily Forward contains "a true epical history of the Jewish mass immigration and the immigrants' adaptation to life in this country," and is "the biggest, most influential Yiddish newspaper in America." ${ }^{17}$ Although the newspaper had been primarily a workingman's newspaper, on January 20, 1906, the Forward began publishing a personal-advice column. Soon, with "the personalized tone and human interest reporting of the Yiddish press," the Bintel Brief evolved into "a trademark of the newspaper" and "an authority on urban living." 18 Ever since then, many scholars and researchers have written about the Bintel Brief letters, but Metzker's A Bintel Brief with a Forward by Harry Golden, is the most thorough.

Different than the Dear Diane letters, which are letters collected only from Asian American women in the early 1980s, A Bintel Brief contains letters published by the Forward since the early twentieth century. The Bintel Brief letters are written by both Jewish women and Jewish men. Referring to the Bintel Brief, Abraham Cahan, the editor of the Jewish Daily Forward wrote in his 1920 memoirs the following:

16 Elain Kim, introduction to Dear Diane: Letters from Our Daughters, by Diane YenMei Wong (Oakland, California: Asian Women United of California, 1983), 3.

17 Isaac Metzker, ed., A Bintel Brief: Sixty Years of Letters from the Lower East Side to the Jewish Daily Forward, Vol. One (New York: Behrman House Inc., Publishers, 1971), 11.

18 Andrew R. Heinze, Adapting to Abundance: Jewish Immigrants, Mass Consumption, and the Search for American Identity (New York: Columbia University Press, 1990), 153. 
People often need the opportunity to pour out their heavy, laden hearts. Among our immigrant masses, this need was very marked. Hundreds of thousands of people, torn from their homes and dear ones, were lonely souls who thirsted for expression, who wanted to hear an opinion, who wanted advice in solving their weighty problems. The 'Bintel Brief' created just this opportunity for them. ${ }^{19}$

Cahan's words clearly show that Jewish assimilation or adaptation to American life was not an easy process. Jewish immigrants suffered heavily from loneliness and family separation. They were eager to tell people their stories and get "advice in solving their weighty problems." In some sense, the birth of the Bintel Brief was a natural outcome of Jewish immigrants' encountering America.

Although the Dear Diane book differs from "A Bintel Brief" in many significant ways, such as its influence, history, and readership, both of them show that Chinese and Jewish immigrant women experienced similarities in their immigrant life, and they share some characteristics in their acculturation, adaptation and resistance to contemporary American culture.

For the sake of this study, I focused on the fifty letters carried in the English-Chinese Dear Diane book and decoded them on the basis of their problems of relationships encountered in family, school, and work. I also selected fifty letters from Metzker's A Bintel Brief that best demonstrate Jewish women's similar experiences to those of the Chinese young women during their Americanization. In my selection, I paid special attention to some comparable items, such as age, gender, and relationship problems both Chinese and Jewish women encountered. Although I focus on the second-generation women's letters from both books, to achieve a broader comparative view, my selection also includes letters from the first-generation women because their questions often concern the same problems the second generation experienced.

As Table 1 shows, of all the letters, those mentioning family relationships occur most frequently. For example, in the Dear Diane letters, as many as 76 percent of the letters discuss relationships with parents. Letters discussing relationships with peers comprise 20 percent. Fewer of these letters concern relationships with teachers and school work. Similarly, according to Table 2, most of the Bintel Brief letters address the parent-child relationship. They comprise as much as 32 percent. The letters mentioning the husband-wife relationship comprise 22 percent. "Inlaw relationship" letters comprise 18 percent. Together with another 8 
percent of letters discussing relationships with relatives, 80 percent of the letters are about family issues. Like their Chinese counterparts, Jewish American women also show a concern over relationships with peers, although they only comprise twelve percent. Table 1 Frequency by Status of Participants
OF the Dear Diane Letters

\begin{tabular}{|l|c|c|}
\hline Party Involved & Frequency & Percentage (\%) \\
\hline Parent/Child & 38 & 76 \\
Peer & 10 & 20 \\
Teacher & 2 & 4 \\
\hline Total & 50 & 100 \\
\hline
\end{tabular}

Table 2 Frequency by Status of Participants OF THE BINTEL BRIEF LETTERS

\begin{tabular}{|l|c|c|}
\hline Party Involved & Frequency & Percentage (\%) \\
\hline Parent/Child & 16 & 32 \\
Husband/Wife & 11 & 22 \\
In-law & 9 & 18 \\
Peer & 6 & 12 \\
Relative & 4 & 8 \\
Society & 4 & 8 \\
\hline Total & 50 & 100 \\
\hline
\end{tabular}

As Tables 1 and 2 show, though the parties involved are peers, relatives, and society, most of the letters are written about the parent-child relationship. A close reading of these letters reveals that they are predominantly about family relationships: the parent-child relationship or the husband-wife relationship. Similarly, Tables 3 and 4 indicate that these immigrant groups have other categories of problems, the dominant ones are still the parent-child relationship and identity problems. 
Table 3 Frequency of Categories of Major Problems in the DEAR Diane LetTers

\begin{tabular}{|l|c|c|}
\hline Problem & Frequency & Percentage (\%) \\
\hline Parent/Child & 24 & 48 \\
Identity & 23 & 46 \\
Sex-Orientation & 1 & 2 \\
Sibling Relationship & 1 & 2 \\
Drug & 1 & 2 \\
\hline Total & 50 & 100 \\
\hline
\end{tabular}

Table 4 Frequency of Major Problems IN THE BINTEL BRIEF LETTERS

\begin{tabular}{|l|c|c|}
\hline Problem & Frequency & Percentage $(\%)$ \\
\hline Parent/Child & 17 & 34 \\
Identity & 14 & 28 \\
Marriage Problems & 9 & 18 \\
Hardship & 6 & 12 \\
Loneliness & 4 & 8 \\
\hline Total & 50 & 100 \\
\hline
\end{tabular}

The difficulties between first-generation immigrants and their daughters, who are mostly American-born and have grown up in the United States, are the most frequently displayed in the mother-daughter relationship, and it is true for both Chinese and Jewish American women. For example, a Chinese daughter expresses her feelings about her parents' being assertive and bossy in their relationship:

\section{Dear Diane:}

At school, teachers tell us to ask questions and to challenge what they say. At home, though, it's just the opposite. Whenever I offer an opinion that is different than what my folks think, they say I'm rude and disobedient. I suppose that I can remain silent in front of them, but isn't there a way that I can express my opinions without them raising the roof?

Opinions Not Wanted ${ }^{20}$

In her answers, Diane Yen-Mei Wong writes:

Dear Opinions: When you are raised in two culturesWestern and Asian-you must often walk a thin tightrope. Going back and forth between the assertive-style 
Western way of communication and the more passivestyle traditional Asian way can be very frustrating. It's not an easy thing to do! Don't let anyone tell you otherwise.

There are some steps you can take to minimize the number of times you get rebuffed. First learn to read your parents' moods. ...

Second, explain to them that if you disagree, you don't mean to upset them or sound disobedient. Rather, you are trying to learn more through discussing it with them. Third, there are many different ways to assert opinions. If you make your parents feel that their way of thinking is wrong, they're going to be defensive and argumentative. ... Tell your parents, "I understand what you're saying, but how about this?" Then present your own view-not as the correct answer, but merely as another suggestion.

You may sometimes feel like you are talking to a wall, but who knows, there may be someone listening on the other side! ${ }^{21}$

In the above letters, although there are issues over which parent-child conflicts arise, the most important are the problematic parent-child communication and the clash of different cultural values and traditions. One can see most clearly how this conflict played out in the first example. On the parents' side, they are heavily influenced by Chinese culture. In Confucianism, showing filial piety towards one's parents is a standard by which parents judge a child good. This cultural value automatically puts parents in an authoritative and domineering position in the parent/child relationship. Thus, if the child challenges what his/her parents say or think, the child will often be regarded as "rude" and "disobedient." This cultural thinking of ten makes parents assertive and dominating and the child "polite" and "obedient" in the parent-child relationship.

From the child's perspective, however, the parent-child relationship is unequal and hierarchical. As the daughter complains in her letter, at school, she receives an American education which encourages her to challenge what her teachers say. But at home, if she questions her parents, she is regarded as "rude" and "disobedient."

Growing up and educated in American culture, which values the concepts of equality, democracy, individualism, and opportunity, this daughter has become Americanized-that is, she has become culturally 
assimilated to mainstream American values. She tries to be informal, casual, and free as a result of American cultural influence. She seeks equality with her parents in the parent-child relationship. She even calls them "my folks" in her letter. Although there is no way of telling whether her parents would be able to read their daughter's letter, they might not like to hear their daughter call them "my folks" instead of "my parents." Also, it might be equally hard for them to accept their daughter as their equal.

The writer's responses deserve special attention. A close reading of them reveals that Wong encourages this young woman to embrace American political and cultural values, such as equality, freedom, and independence. Although she recognizes the difficult situation in which one is raised in two cultures-Western and Asian-she does not want this young woman to give up. Instead, throughout her responses, she insists that this young woman should not fear to talk with her parents and even if it does not work, "who knows, there maybe someone listening on the other side!" The advice offered is positive and encouraging in tone by American standards. It seems that it is reasonable, according to the editor, for the second-generation women to identify themselves with American culture and values and resist traditional Chinese parenting culture. As a whole, Wong's responses are considerate, understanding, and instructive.

Likewise, a Jewish mother also expresses her disappointment with her two sons and one daughter:

Worthy Editor:

I consider myself a progressive woman who thinks there should be no difference between Jews and Christians. ... Now, however, when my daughter has fallen in love with a Gentile, I have become one of those mothers who interferes because I am against this match. I am not one of those fanatic parents who warn their children that they will disown them because of it, but I'm trying with goodness to influence my daughter to break up with the boy. My daughter argues with me: "why? You always used to say that all people are equal." She is educated, she knows how to talk to me, and often I have no answers to her arguments. But I feel this is no match for 
my daughter. Her friend comes here often, and as a person he appeals to me, but not as a husband for her. . .

Respectfully,

A Mother 22

The editor's answer is as follows:

Answer:

You yourself answered everything in your letter, and our opinion is the same as yours. Your daughter should also understand that the match is not a good one. But she is infatuated with the young man. And when one is in love, then all the sensible arguments are worthless. ${ }^{23}$

The above letter expresses the mother's anxiety about her daughter's falling in love with a "Gentile" (a person of non-Jewish faith) and her daughter's ignoring her advice. However, the different intergenerational perspectives on interethnic relationship play a significant role in the Jewish mother-daughter relationship. As the letter reveals, the mother-daughter conflict is mainly triggered by different ethnic viewpoints. Although the mother in the letter considers herself a "progressive woman who thinks there should be no difference between Jews and Christians" and believes that "as a person he appeals to me," this does not mean that she can accept this appealing Christian man to be her son-in-law.

Obviously, the Jewish American mother cannot accept the differences between Jews and Christians in her life. To some extent, she still harbors negative opinions of Christians in her heart. Her own religious commitment makes her oppose her daughter's marriage with the Christian man. However, on her daughter's side, she is fully aware of the meaning of the pursuit of happiness. Also she is more tolerant than her mother of religious differences. Growing up under the influence of American culture, this daughter does know how to argue with her mother. To achieve her own happiness, the daughter even attempts to persuade her mother to agree with her decision. Unfortunately, even if she is unable effectively to answer her daughter's arguments, the mother still does not give up her ideas and would try "with goodness to influence my daughter to break up with the boy."

The Jewish American mother's letter shows that when Jewish immigrant women encounter America, intergenerational conflicts are unavoidable. For the Jewish mother, it is unbearable to accept the "boy" as her son-in-law, simply because he is a Christian. For the daughter, however, 
marriage with a Christian is an acceptable form of assimilation to American life.

This letter contrasts with the Dear Diane letter above in that the Jewish daughter is more independent and free in speech and behavior. Despite her mother's resistance, for example, the Jewish American daughter insists that she should still continue her relationship with the Gentile and to justify it, she uses her mother's words "All people are equal," which essentially reflect American democracy and equality. However, the young Chinese American woman cannot be free to do so since in Chinese culture, it will be considered "rude" and "disobedient" for children to do so to their parents. The two letters above suggest that, though both the young Chinese and Jewish women are educated in American culture and both feel restricted by their own ethnic culture, comparatively, the young Jewish American woman still has more freedom and independence than her Chinese counterpart. Thus, it can be inferred that the young Chinese woman has experienced greater difficulty arising from her own ethnic culture than the Jewish American woman during her assimilation or adaptation to American life.

Noticeable with this letter is the editor's answer. While reading it, one can feel the strong tone of the editor's approval of the Jewish American mother's opinion. By saying "our opinion is the same as yours," the editor conveys to the mother his empathy but points out the futility of opposing the daughter, since as he advises, love will dominate. Yet, it indicates that, since this letter was written in 1928, Jewish immigrants also encountered similar generational problems as did second-generation Chinese Americans and to a large extent, the problems are often a result of conflicting cultural and ethnic values. This was especially so when the second-generation immigrants came of age.

Aside from the dominant parent-child conflicts, the identity problems are another concern for the young Chinese and Jewish American women. For example, in the Dear Diane letters, as many as twenty three out of fifty mention identity problems, comprising 46 percent of the total. As compared with Chinese women, only fourteen Jewish American women talk about their identity crises, comprising 28 percent of the total. However, identity problems occupy second place both in the Chinese and Jewish women's letters and this shows that during their assimilation to American life, neither the young Chinese nor Jewish women find it easy to identify themselves as "pure" Americans. For example, the following two examples indicate:

Dear Diane:

When I was little, my parents tried to force me to learn Chinese, but I always resisted. I guess that I was too 
concerned about being 100\% American like all my friends.

Now that I'm 25, I realize that maybe I should've listen to my mom a little more. I've never been able to share my feelings with my parents or talk with my grandparents. Since they are getting older, I feel like I'm missing out on all of what they have learned.

I've decided to take language classes myself, but I just wanted to encourage other young people to try to maintain their family's language. Don't succumb to the pressures that I felt about trying to be American.

Going To Be Bilingual ${ }^{24}$

\section{Dear Editor,}

I am writing you, with my dear husband's permission, about the resentment we feel over our daughter-in-law, and I ask your advice. . . . Our daughter-in-law was never too friendly toward us, but we overlooked a great deal. A short time ago, when my husband and I went there, she suddenly announced that she wanted us to visit our grandchildren only once in two weeks, and that we should avoid coming to them on weekend when they have guests.

I didn't know at first what my daughter-in-law meant, but she explained that, as her children were growing up, she didn't want them to learn from us to speak English with a Jewish accent. Our dear daughter-in-law wasn't even ashamed to tell us that we didn't fit in with her group of friends who were real Americans, while we were foreigners.

It's true we're not American-born (we came to this country over forty years ago) and our English is not "perfect," but we are very hurt by our daughter-in-law's remark. I answered her then that in our youth we had no time to learn the English that was spoken in high society because we had to work hard to raise a college-educated husband for her. I told her my husband of ten had to work overtime in order to be able to send our son to college, to make him a professional man. ... 
We ask you, is this right? Should children act this way? What can we do, dear Editor, since we miss our grandchildren so? We are hurt and want to know whether we must obey these rules laid down by our daughter-in-law. Please answer soon.

With heartfelt thanks,

Grandma and Grandpa ${ }^{25}$

From the above examples, one finds that the younger generation of Chinese and Jewish women has an identity crisis. The young woman in the first example refuses to learn Chinese in order to be "100\% American" like all her friends. In her eyes, to achieve and maintain this American identity, she should not learn Chinese. In this sense, the Chinese language becomes a benchmark by which one can be judged as an American or not. But when she grows older, this young woman begins to feel as if she had missed out on what her grandparents and parents had learned, so she decided to take Chinese language classes herself. From this example, one can see that the identity is fluid and changing with the daughter's growing up.

Indeed, on the one hand, the younger generation of Chinese American women was born and grew up in the United States. Most of them can get a good school education, and they desire to be the same as their American counterparts. In other words, they want to assimilate socially and culturally into American mainstream culture. On the other hand, because of their parents' cultural and ethnic differences, they are still inevitably linked to their family lineage, heritage, and tradition. They are still Chinese Americans.

Likewise, the second example indicates that growing up for Jewish American women also challenges their sense of identity. Although the Bintel Brief letters do not mention ethnic/racial differences as of ten as their Chinese counterparts, this does not mean that Jewish women take it for granted that they are true Americans. Actually elements, such as religion and language, play a role in Jewish women's acculturation, assimilation, or even resistance to American society and life. From the daughter-in-law's reaction to her parents-in-law in this example, one sees maintaining her or her children's American identity is worthwhile even if it means alienating her parents-in-law from her family.

The two example letters mentioned above show a dilemma in the young Chinese and Jewish American women's efforts to assimilating to American society and culture. On the one hand, since they were born and grew up in America, they would like to be treated like real Americans not foreigners. But the older they grow, the more they realize that they 
are still hyphenated Americans. This is particularly true for Chinese American women. As compared with Jewish American women, the Chinese have another hindrance in their assimilation process: their physical differences.

However, to gain and keep their American identity, the younger generation must break away from the influence of their parents' culture. Just as occurred when Jewish daughter-in-law distinguished with her parents-in-law above, such treatment inevitably engenders more family conflicts and crises.

In the Bintel Brief letters, marriage problems rank the third highest out of all the categories involving Jewish American women. Although few of the English Dear Diane letters directly address marriage problems because of the Asian American women's younger age, several letters express concerns with intermarriage.

For example, one letter writes:

Dear Diane:

My mom always told me as I was growing up that when white boys look at you, they're thinking no good of you and that I should avoid them at all costs.

I'm 19 and have just met my Chemistry Lab teaching assistant. He has blond hair and the most beautiful blue eyes. He's got the kind of personality that I have found only in Caucasians, and not in Asians. I like him a lot, but I'm also very conscious of what my mom told me about whites. Maybe he just finds me exotic. What should I do?

Loving Chemistry 26

In her responses, Wong writes:

Dear Loving Chemistry:

Beware of relationships that are based only on physical characteristics or on a stereotyped personality. You say that you have just met him, so you don't know very much about him and what he is like on the inside. Yet, you say he has characteristics that Asian guys don't. You're not only treating Asian men on the basis of a stereotype, but you're also doing it to your instructor. Neither what your mom said about whites nor what you have said is necessarily true.

What may be even more dangerous is that your instructor may do the same to you, and see you only as a stere- 
otypical Asian American woman-exotic and mysterious. If he does anything more to you than that, you may find this type of relationship a bit shallow and boring in the long run.

Instead of making broad generalizations about Asian men, or snap judgments about blue-eyed blonds, take your time and give each man a chance to show you his true colors.

Don't jump into this relationship solely on the basis of your body chemistry!27

Similarly, a Bintel Brief letter to the editor:

Dear Friend Editor:

We've live through a lot, and now we face another problem.

My husband and I are not religious, but we lead a traditional Jewish life. Therefore, it was a blow for us when our daughter, without telling us, married a non-Jew. When she came to tell us what she had done, she kept promising us that she and her husband, who is a learned man, planned to keep some of the Jewish tradition in their home. We were angry with her, but since we didn't want to become estranged from our daughter, we accepted the inevitable.

Not long ago I was at my sister's home and I was told that since my daughter's husband is not Jewish, they cannot make a brith [ritual circumcision]. We don't know if this is so, but we, and especially our daughter, are very upset. She hopes to have a son and wants him to be named for her grandfather, who was a religious man and whom she loved dearly. Our non-Jewish son-in-law is not religious, but she loves our daughter very much and wants to do everything he can to make her happy.

I ask you not to delay giving us your answer because the time is short.

With thanks and respect,

B.R. ${ }^{28}$

The editor replies: 
Though the "Bintel Brief" column doesn't print letter about this type of problem, we will make an exception in your case, which shows the confusion in Jewish life today. We don't give advice on religious matters because, first, we don't know all the details, and second, there are, thank goodness, enough rabbis here who can handle these questions. Therefore, it would be advisable for you to consult a rabbi about this. Finally, we want to note that many children of mixed marriages are very disturbed when they grow up, because when they are asked whether they are Jews or Christians, they don't know what to answer. ${ }^{29}$

Both letters concern the issue of intermarriage, though the difference is that the young Chinese American woman likes a white man because of his physical beauty, while the Jewish American daughter married a non-Jew against her parents' wishes. In regards to their daughter's attitude toward a man of another ethnic group, it is surprisingly similar yet there is a marked difference between the first-generation and second-generation Chinese and Jewish immigrants. For example, the first generation still has close connections to their homeland and culture and do not encourage their daughter to marry somebody from a different ethnic group. In the Chinese mother's case, she is assertive saying that white men are no good and her daughter should stay away from the white teaching assistant; in the Jewish American mother's case, though she and her husband are not religious people, Jewish tradition and culture do not accept outmarriage. Since their daughter has already married, they have to "accept the inevitable." Both cases reflect that neither Chinese nor Jewish culture, religion, and values encourage exogamy and this is most evident among first-generation immigrants.

It is also surprising to find that the editors' responses share almost the same characteristics - caution and warning. For example, in Wong's responses, though she seems to be objective about making an assertive statement about whites, she uses the words "Beware of relationships that are based only on physical characteristics or on a stereotyped personality" and "Don't jump into this relationship solely on the basis of your body chemistry!" to warn the young Chinese woman that her love for the white man might be an illusion and won't last long, therefore indirectly supporting her mother's words about whites. In the Bintel Brief editor's answer, this "cautious" tone is more clearly demonstrated. The editor first points out that the Bintel Brief column does not print this kind of letter because it shows "the confusion in Jewish life today." Then the 
editor refuses to give any advice on religious matters but at the end of his answer, the editor's word: “. . . many children of mixed marriages are very disturbed when they grow up, because when they are asked whether they are Jews or Christians, they don't know what to answer." This sounds more like a warning rather than advice. So it is reasonable to believe that, in providing answers, perhaps both editors identify strongly with their own ethnic group and thus answer the questions from a mixed perspective involving their own ethnic culture and American culture.

Although the women writers in the Dear Diane and the Bintel Brief letters are different in some respects, such as their different ethnic backgrounds and times of arrival, the Chinese and Jewish American women share more commonalities with each other in their encounters with America. In other words, the process of Americanization has affected them and their families in a similar way. First of all, the generational parent-child problems exist in both cases. In the Dear Diane and the Bintel Brief letters, it is either the daughter who complains about the relationship with her parents-usually her mother-or the mother who shows dissatisfaction with her daughter. Such conflicts pervade almost every aspect of their lives. Usually these generational problems arise from different cultural influences on the parts of parents and daughters.

Second, due to cultural, ethnic, and religious influences, the conflicts expressed in both groups of letters cannot be avoided and resolved. The older generation has been strongly influenced by their ethnic cultures and traditions so much that, though they live in America, they cannot give up their traditional cultures and practices. In other words, cultural, structural and marital assimilation is more difficult for them than for their children. Rather, they would like their daughters to inherit and pass on their own ethnic cultures to the third or the fourth generations.

However, since the younger generation of women was born and raised in America, most of them can get a better American education than their parents. They want to treat their parents in the way that a "real" American treats his or her parents, that is, with a truly equal, free, and independent spirit. This spirit can often lead to a direct conflict with first-generation parents. Neither of the two parties gives in to each other.

Lastly, letters from both Chinese and Jewish American women reveal a sense of identity crisis. As both groups of letters of the generational conflicts reveal, the younger generation of women of ten identify themselves more as American than their parents do, but they feel lost when they find that their American identity is neither recognized by mainstream society nor by their parents. Therefore, assimilation for young Chinese women and Jewish women is by no means taken for granted. 


\section{REFERENCES}

Alba, Richard, and Victor Nee. Remaking the American Mainstream: Assimilation and Contemporary Immigration. Massachusetts: Harvard University Press, 2003.

Asian Women United. "Asian Women United (AWU) of California." Accessed March 31, 2011. http://www.asianwomenunited.org.

Berg, Justin Allen. "Race, Class, Gender, And Social Space: Using an Intersectional Approach to Study Immigration Attitudes." The Sociological Quarterly, 51(Spring 2010): 278-302.

Bourne, Randolph S. "Trans-National America." In World War Issues and Ideals: Readings in Contemporary History and Literature, eds. Morris Edmund Speare and Walter Blake Norris, 343-351. Boston: Ginn and Company, 1918.

Gabaccia, Donna. "Immigrant Women: Nowhere At Home?." Journal of American Ethnic History, 10 (Summer 1991): 61-87.

Gans, Herbert. Introduction to Ethnic Identity and Assimilation: The Polish-American Community: Case Study of Metropolitan Los Angeles, by Neil Sandberg, vii-xiii. New York: Praeger Publishers, 1974.

Heinze, Andrew R. Adapting to Abundance: Jewish Immigrants, Mass Consumption, and the Search for American Identity. New York: Columbia University Press, 1990.

Kim, Elaine. Introduction to Dear Diane: Letters from Our Daughters, by Diane Yen-Mei Wong, 1-3. Oakland, California: Asian Women United of California, 1983.

Metzker, Isaac, ed. A Bintel Brief: Sixty Years of Letters from the Lower East Side to the Jewish Daily Forward, Volume One. New York: Behrman House Inc., Publishers, 1971.

. ed. A Bintel Brief: Letters to the Jewish Daily Forward, 19501980, Volume Two. New York: The Viking Press, 1981.

Moore, Deborah D. "At Home in America?: Revisiting the Second Generation." In Immigration, Incorporation and Transnationalism, ed. Elliot Robert Barkan, 143-154. New Brunswick: Transaction Publishers, 2007.

Sandberg, Neil C. Ethnic Identity and Assimilation: The Polish-American Community: Case Study of Metropolitan Los Angeles. New York: Praeger Publishers, 1974.

Wong, Diane Yen-Mei. Dear Diane: Letters from Our Daughters. Oakland, California: Asian Women United of California, 1983. 
- Dear Diane: Questions and Answers For Asian American Women. Oakland, California: Asian Women United of California, 1983.

Yetman, Norman R., ed. Majority and Minority: The Dynamics of Race and Ethnicity in American Life, 6th Edition. Boston: Allyn and Bacon, 1999. 